\title{
Bedrock aquifers and population growth in the Denver Basin, Colorado, USA
}

\author{
1. U.S. Geological Survey, Denver, Colorado, USA.Email: moore123@aol.com \\ 2. Denver Museum of Nature \& Science, Denver, Colorado, USA.Email: Bobraynolds@yahoo.com
}

The Denver Basin bedrock aquifer system consists of Tertiary and Cretaceous age sedimentary rocks known as the Dawson, Denver, Arapahoe and Laramie-Fox Hills aquifers. The number of bedrock wells has increased from 12,000 in 1985 to over 33,700 in 2001 and the withdrawal of groundwater has caused water level declines in excess of 75 meters. Water level declines now range from 3 to 12 meters per year in the critical Arapahoe Aquifer.

The groundwater supplies were once thought to be sufficient for 100 years but there is concern that they may be depleted in 10 to 15 years in areas on the west side of the basin. Groundwater is being mined from the aquifer system because the withdrawal through wells exceeds the rate of recharge. Increased groundwater withdrawal will cause further water level declines, increased costs to pump groundwater, and reduced yield from existing wells. In the Denver Basin, hydrologists have some capability to monitor declines in water levels for the Arapaho Aquifer, but generally have a limited ability to monitor water use. More complete and accurate water use data are needed to predict groundwater longevity for the Arapahoe Aquifer.

The life of the Arapahoe Aquifer can be extended with artificial recharge using imported surface water, water reuse, restrictions on lawn watering, well permit restrictions and other conservation measures. Availability of groundwater may limit growth in the Denver Basin over the next 20 years unless residents are willing to pay for additional new sources of supply.

\section{Introduction}

In Colorado (Figure 1), the Denver Basin aquifer system is an important source of water for municipal use in the Denver and Colorado Springs metropolitan areas and in the rapidly expanding urban corridor that connects these two cities. Extensive exploitation of the aquifer system has occurred in the last 25 years especially near the center of the basin in Douglas and El Paso counties, where rapid urban growth continues and surface water is lacking. Groundwater is being mined from the aquifer because the discharge by wells exceeds the rate of recharge. Increased groundwater withdrawal is causing large water level declines, reduced groundwater storage, and increased costs of production (Nichols et al., 2001).

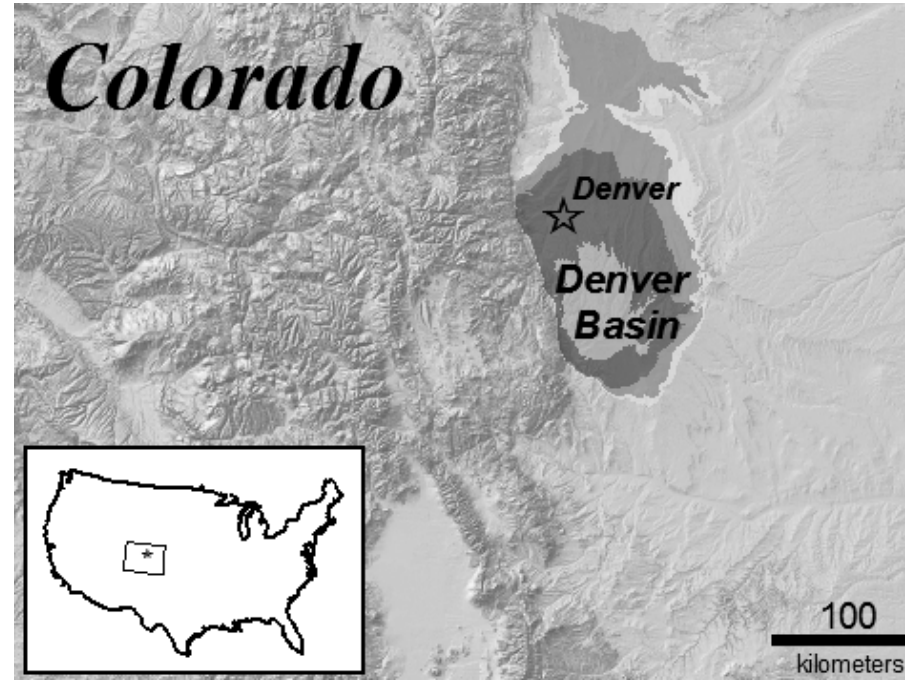

Figure 1 Location map of the Denver Basin in the United States. The Denver Basin lies immediately east of the Rocky Mountains in Central Colorado.

The Denver metropolitan area is one of the fastest growing in the United States (Figure 2), with a population that has increased from 1.7 million in 1990 to over 2.2 million in 2005. This population growth has produced a corresponding increase in the demand for potable water. The Denver metropolitan area relies mostly on surface water. However, over the past 20 years, much of the potable water for new housing constructed south of Denver is derived from groundwater. The majority of the 250,000 residents in the southern Denver metro area obtain water from the Dawson, Denver, and Arapahoe aquifers. The water is primarily used for domestic purposes and urban recreation, mainly golf courses.

The bedrock aquifers in the Denver Basin (Figure 3) have supplied groundwater to the Denver area for more than 100 years. A history of water development in Colorado is shown in Table 1. Ground-

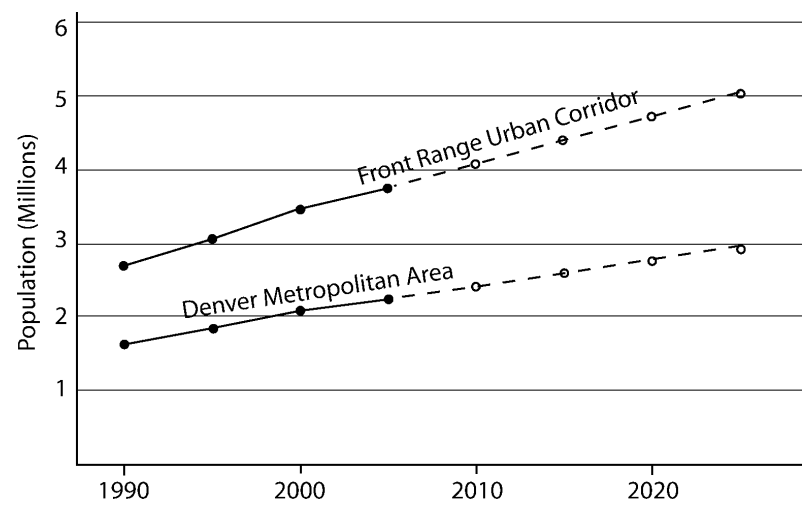

Figure 2 Population change in the Denver Area. The population is climbing due largely to immigration as the Colorado Front Range area is a desirable place to live. 


\section{Where Does YOUR Water come from?}

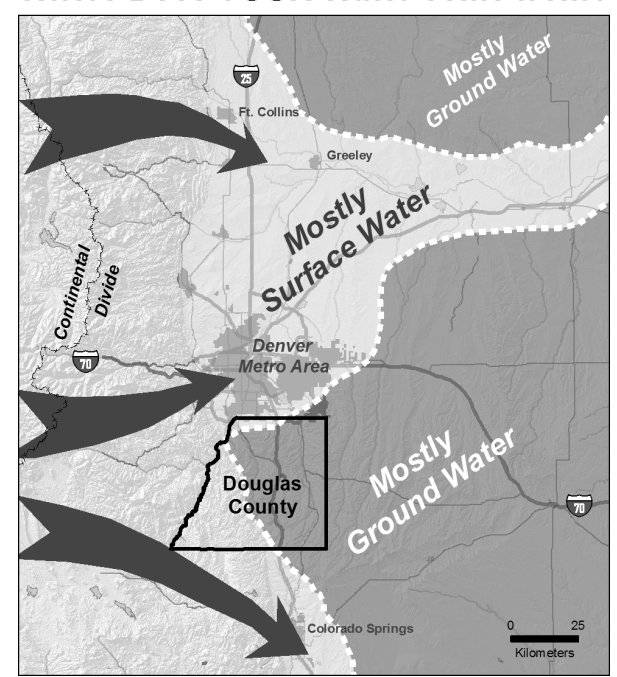

Figure 3 Sources of water in the Denver Basin. Water supplies for the Denver region are derived from renewable surface water, including water transported by tunnels from across the Continental Divide (arrows) and non-renewable groundwater in areas where surface water supplies are not yet available.

water development began in 1883 when it was discovered that Denver could be supplied with water from bedrock aquifers. The artesian aquifer pressure was used for decorative fountains, and to provide power for elevators and church organs. The unusual high pressure head of the artesian aquifer led to a rapid increase in the number of wells and by 1890 , there were 400 bedrock wells in Denver. With increased use, the artesian head declined and groundwater no longer flows to the land surface (McLaughlin, 1955). Presently the Denver metropolitan area uses mostly surface water, while the more recently settled areas south of the city are reliant on groundwater (Figure 4). Summaries of the groundwater history are provided by Topper et al., 2003 and by Topper, 2004. The present paper updates Moore et al., 2004

Table 1 History of water development in Colorado, 1299-2004

\begin{tabular}{|c|c|}
\hline Date & Water Event \\
\hline 1299 & $\begin{array}{l}\text { Cliff dwellers in southwest Colorado abandon } \\
\text { Mesa Verde because of shortage of food and } \\
\text { water and attacks by nomadic tribes }\end{array}$ \\
\hline 1787 & $\begin{array}{l}\text { First surface water Diversion in Eastern Colo- } \\
\text { rado (near Pueblo) }\end{array}$ \\
\hline 1803 & $\begin{array}{l}\text { US acquires a part of Colorado as part of the } \\
\text { Louisiana Purchase }\end{array}$ \\
\hline 1858 & $\begin{array}{l}\text { Gold discovered in Denver (Cherry Creek and } \\
\text { Platte River) }\end{array}$ \\
\hline 1876 & Colorado becomes 38 th state \\
\hline 1880 & $\begin{array}{l}\text { Appropriation water doctrine adopted by Colo- } \\
\text { rado }\end{array}$ \\
\hline 1884 & $\begin{array}{l}\text { First Arapahoe bedrock aquifer well drilled in } \\
\text { Colorado }\end{array}$ \\
\hline 1957 & $\begin{array}{l}\text { Colorado State Engineer issues permits for bed } \\
\text { rock aquifer wells }\end{array}$ \\
\hline 1968 & $\begin{array}{l}\text { Wells are made subject to appropriation doctrine } \\
\text { Tributary groundwater regulations }\end{array}$ \\
\hline 1973 & $\begin{array}{l}\text { Colorado Senate Bill } 213 \text { set } 100 \text { year life for } \\
\text { bedrock wells }\end{array}$ \\
\hline 1980 & Denver places water meters on houses \\
\hline 2002 & $\begin{array}{l}\text { Major drought gives awareness of water } \\
\text { problems }\end{array}$ \\
\hline Post-2002 & $\begin{array}{l}\text { Increased pricing of water and for new home } \\
\text { connections }\end{array}$ \\
\hline
\end{tabular}

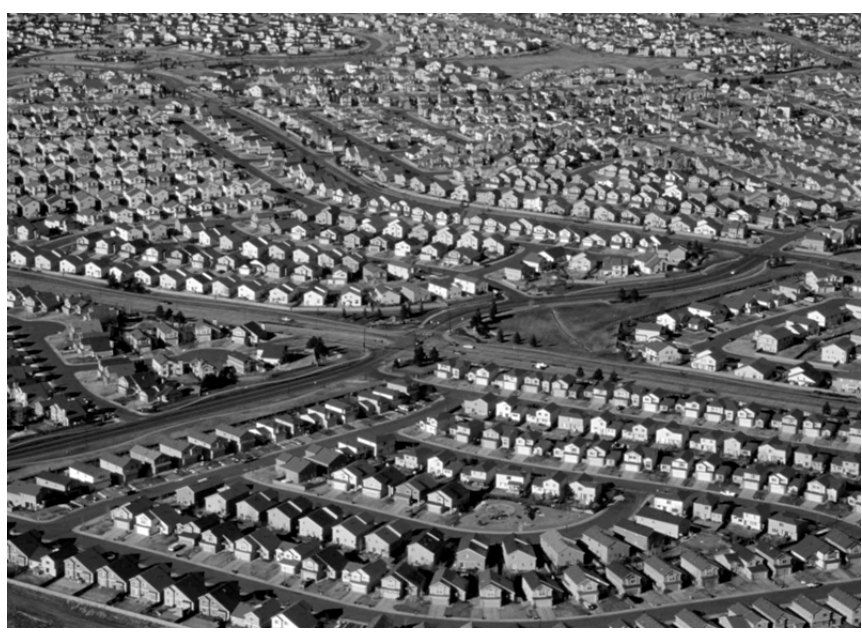

Figure 4 Highlands Ranch is a rapidly growing community in Douglas County, south of Denver. This community is supplied by both surface water and groundwater.

\section{Climate and geologic features of the Denver Basin}

The Denver Basin is semiarid having 36 centimeters (14 inches) of annual precipitation. Most of the precipitation is lost through runoff and evapotranspiration and it is estimated that less than 1 percent recharges the aquifers. The aquifers are components of a regressive beach system and overlying fluvial clastics deposited in a subsiding foreland basin as the Cretaceous Interior Seaway retreated from Western North America and the Rocky Mountains were uplifted during the Laramide Orogeny.

\section{Hydrogeology}

The bedrock aquifer system of the Denver Basin occupies an area of 17,300 square kilometers that encompasses the Denver metropolitan area. The Denver Basin extends from Greeley in the north to Colorado Springs in the south. The Denver Basin bedrock aquifer system consists of Tertiary and Cretaceous age interbedded layers of sandstone, conglomerate, and shale (Robson, 1989). For the purpose of water management, the aquifer system has been subdivided into the Dawson, Denver, Arapahoe, and Laramie-Fox Hills aquifers (Topper et al., 2003). The stratigraphy of the aquifer system is complex, with water-bearing sandstone and conglomerate beds interbeded with shales.

In 1985, 12,000 wells withdrew water from the Dawson, Denver and Arapahoe aquifers. By 2001, the number of wells had grown to 33,700 . The withdrawal of groundwater has caused water level declines of as much as 76 meters with water level decline rates presently ranging from 3 to 12 meters per year in the prolific Arapahoe Aquifer. As a result, individual well yields have declined, and pumping costs have increased. The groundwater supplies were once thought by the State Engineer to be sufficient for 100 years but we estimate they are only adequate for 10 to 15 years in areas on the west side of the basin. The 100-year estimate was an arbitrary time frame established to restrict water use. Water levels in these aquifers continue to decline because there is little or no recharge. Thus, the groundwater is being mined.

The Arapahoe Aquifer consists of up to 100 meters of interbedded conglomerate, sandstone, and shale. This aquifer has the largest well yields in the basin, with flow rates of up to 45 liters per second because of large hydraulic conductivity, high porosity, and greater aquifer thickness. 
Over most of the Denver Basin the aquifers are confined (water levels rise above the aquifers); however, due to the rapid water level declines, they are changing to unconfined aquifer conditions (water levels fall to within the aquifer). The areas most vulnerable to water level declines are at the edges of the basin where the aquifers are shallow and tilted towards the surface (Figure 3). It is not well understood how the aquifer system consisting of water-bearing layers interbedded with impermeable shales will respond as water levels drop below the tops of each aquifer. The conversion to unconfined conditions will probably result in a decrease in the rate of water level decline.

\section{Legal framework}

The first Arapahoe wells were drilled in 1883 in downtown Denver. At that time the artesian head was as much as 30 meters above the land surface. Many Arapahoe wells were drilled in Denver, and by the beginning of the twentieth century, almost all the wells had ceased to flow at the surface.

Well drilling continued in a more or less uncontrolled manner through the first half of the twentieth century. Between 1957 and 1969, well permits were issued by the Colorado State Engineer based on a finding of no injury to adjacent or downstream water users. It was assumed that bedrock aquifers were not connected to streams and therefore, there was no injury to surface water rights. In 1971 the Colorado state statutes were changed to require the State Engineer to show that unappropriated water was present before a well permit could be issued (Hobbs, 2004).

In 1973, Colorado Senate Bill 213 changed the standards for well permit evaluation and, although it did not define "non-tributary" groundwater, it did set criteria for appropriation from the bedrock aquifers. The total recoverable volume of water used to determine the rate would be determined by land area and saturated sand thickness.

In 1985, Colorado Senate Bill 5 changed the criteria for aquifer management and the determination of the availability of non-tributary groundwater. The standard was a land owner could appropriate the groundwater in the bedrock aquifers beneath the land that was owned at a rate that would insure it would last for at least 100 years. To sustain a 100 -year life, the total annual withdrawals were limited to $1 \%$ of the calculated total recoverable water underlying the land (Topper et al., 2003).

\section{Groundwater development south of Denver}

Water levels in Douglas County (located south of Denver) are falling dramatically, in many areas exceeding $25 \mathrm{~mm}$ (1 inch) per day, but this has not deterred population growth (Figures 5 and 6). According to a recent South Metro Water Supply Study (2003), the Douglas County area should implement measures to reduce the volume of groundwater withdrawal. As water levels decline, well yields will decrease. Because the unit cost of each gallon of pumped water will increase, drilling additional wells may not be economic in the long run (Alley et al., 1999).

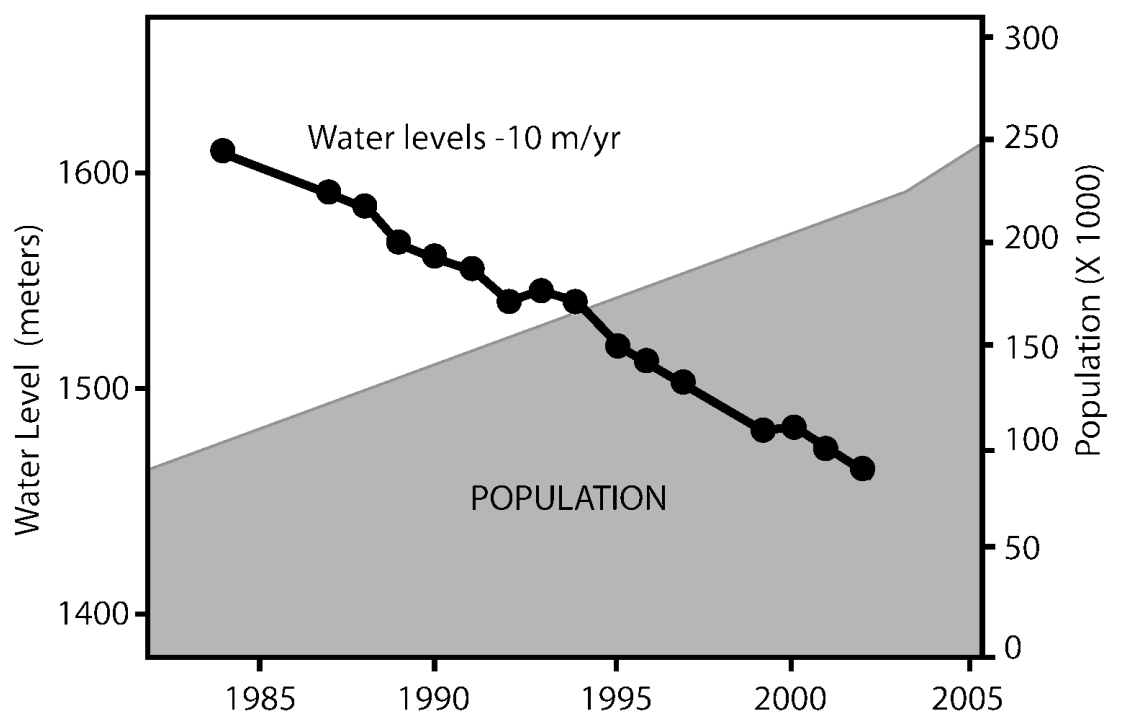

Figure 5 Population vs. water level changes in Douglas County. The crossing curves are a warning that changes in water supply are ahead.

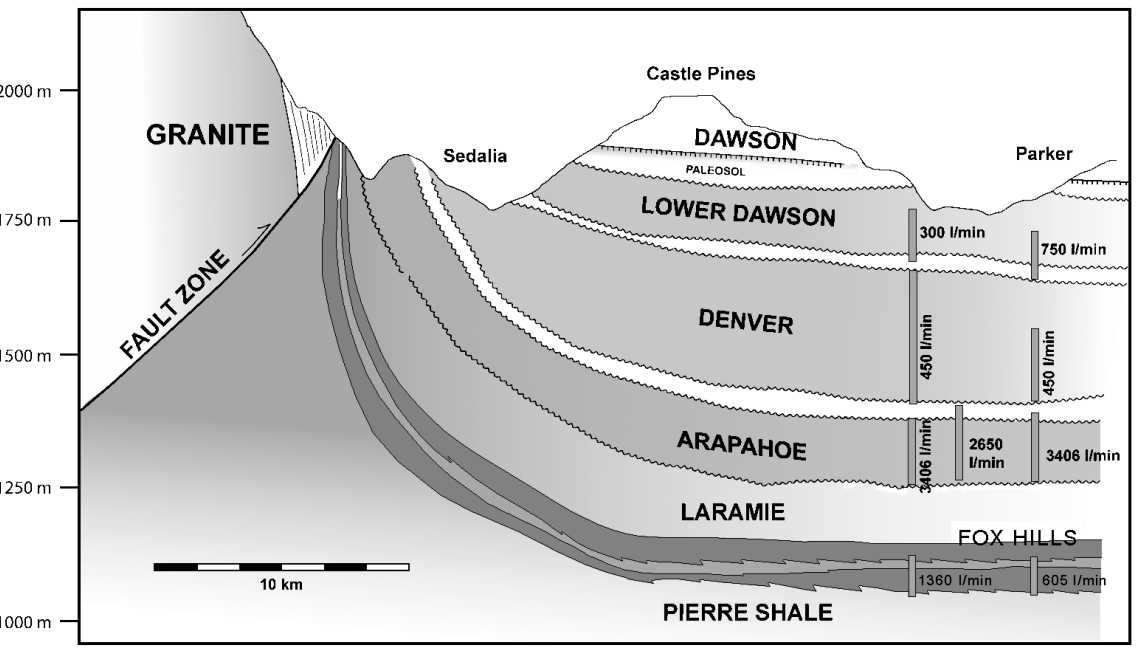

Figure 6 Cross section through the western Denver Basin. This west to east section illustrates the geometry of the bedrock aquifers in the basin, and emphasizes the relatively high water flow rates from the Arapahoe Aquifer.

It is believed by water managers that the life of the Arapahoe Aquifer can be extended with artificial recharge, water reuse, restrictions on lawn watering, well permit restrictions and conservation measures. The region may reduce its reliance on Denver Basin groundwater by pursuing renewable surface water sources.

The following is a summary of the Douglas County groundwater problems:

- Continued reliance on the deep aquifers to meet demands will result in very large increases in capital and production costs in the foreseeable future, impacting the economic viability of groundwater as a resource.

- Expected declines in artesian pressure and groundwater levels will seriously impact the ability of water providers to efficiently produce groundwater.

- Reduction of artesian pressure over the next 20 years will require drilling more wells to produce the same volume of water. The required infrastructure will make groundwater pumping to meet future demand extremely costly.

Currently, the Centennial Water and Sanitation District supplies the Highlands Ranch community in Douglas County with water and operates a well field completed in the Denver, Arapahoe, and Laramie-Fox Hills aquifers. In addition, the district has tributary 
surface water rights on the South Platte River system and diverts tributary water directly from the South Platte and through alluvial wells. During periods of surplus tributary water, treated water from the South Platte system is injected in a series of experimental Aquifer Storage and Recovery (ASR) wells in each of the three aquifers. The ASR wells are equipped with down-hole control valves that allow both extraction and injection through the pump column. While injected volumes have been limited, this project has established the feasibility of aquifer injection if surplus surface water were to be available.

\section{Current investigations and research}

Current investigations to provide data and analyses of the Denver Basin aquifers are being made by the U.S. Geological Survey, the Colorado Geological Survey, the Colorado State Engineer, the Colorado School of Mines, various consulting firms, the U.S. Bureau of Reclamation, and the Denver Museum of Nature \& Science.

A U.S. Geological Survey three-year study of the Denver Basin was started in 2004. The objective of the study is to improve the understanding of the hydrogeology of the basin. Evaluations will be made of the monitor well network and water level decline rates. A digital computer model of the basin will be constructed.

\section{Recommendations}

Establish a unified management system for the Denver Basin bedrock aquifers. The current system with a myriad of small water managers is unworkable for the long term.

More observation wells should be added to define water level changes. Production wells should not be used as observation wells. Today we are largely dependent on municipal wells for water level data.

Methods should be used to conserve groundwater. For example, reuse water, reduce lawn watering, deny well permits in critical decline areas, place a warning on home sales contracts that the water supply is limited, increase tap fees for water connections, import surface water supplies, and use artificial recharge when excess surface water is available.

\section{Acknowledgements}

We acknowledge the helpful reviews of Thomas Winter, Ralph Heath and Leonard Konikow. Raynolds has received support from the National Science Foundation (Grant number EAR 0345910), Parker Water and Sanitation, and the City of Aurora Utilities District.

\section{References}

Alley, W.M., Reilly, T.E., and Franke, O.L., 1999, Sustainability of groundwater resources: U.S. Geological Survey Circular 1186, 79 p.

Hobbs, G. J., 2004, Citizen's guide to Colorado water law: Colorado Foundation for water education, $33 \mathrm{p}$.

Moore, J.E., Raynolds, R.G., and Barkmann, P.E., 2004, Groundwater mining of bedrock aquifers in the Denver Basin-past, present, and future: Environmental Geology, p.63-68.

McLaughlin, T.G., 1955, Ground water in the Denver metropolitan area, in: Rocky Mountain Association of Geologists 1955 Field Conference Guidebook, p. 60-67.

Nichols, P.D., Murphy, M.K., and Kenney, D.S., 2001, Water and growth in Colorado, a review of legal and policy issues: Natural Resources Law Center, University of Colorado School of Law, Boulder, Colorado, $191 \mathrm{p}$.

Raynolds, R.G., 2004, Stratigraphy and water levels in the Arapahoe Aquifer, Douglas County area, Denver Basin, Colorado, The Mountain Geologist, v. 41 , p. $195-210$.
Robson, S.G., 1989, Alluvial and bedrock aquifers of the Denver Basin, U.S Geological Survey Water Supply Paper 2302, 40 p.

South Metro Water Supply Study Summary, 2003, Prepared for the South Denver Metro Water Supply Study Board, Black \& Veach and other consultants, Denver, Colorado, 20 pages.

Topper, R., Spray, K.L., Bellis, W.H., Hamilton, J.L., and Barkmann, P.E., 2003, Ground Water Atlas of Colorado: Colorado Geological Survey, $210 \mathrm{p}$.

Topper, R., 2004, Aquifers of the Denver Basin, Colorado, The Mountain Geologist, v.41, p. 145-152.

John E. Moore received a BA from Ohio Wesleyan University and a Ph.D. from the University of Illinois. He was a hydrologist with the US Geological Survey from 1960-89. He is an adjunct professor at Metro State College (Denver, CO) and works as a consulting hydrogeologist. He is a past president of the International Association of Hydrogeologists. He has published more than 80 technical papers and 4 books.

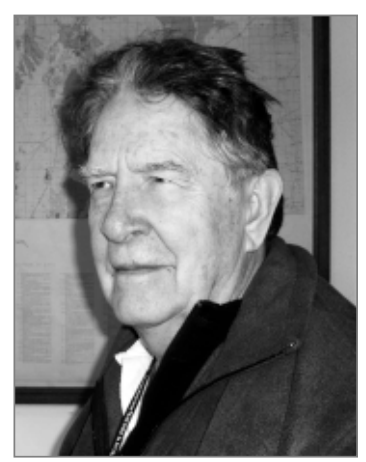

Bob Raynolds does research on the stratigraphy of synorogenic sediments. He is a Research Associate at the Denver Museum of Nature \& Science. He teaches field methods to geophysics students at the Colorado School of Mines and adult education classes at the Denver Museum of Nature \& Science. He is interested in the overlap (or lack of overlap) between scientific knowledge and public policy.

Marieke Dechesne is a researcher at the Denver Museum of Nature \& Science. She teaches GIS methods at the Colorado School of Mines and the University of Colorado, Boulder. She is interested in three dimensional visualization of complex geologic features, She is working on optimizing aquifer visualization so that the public can better understand water resource issues.
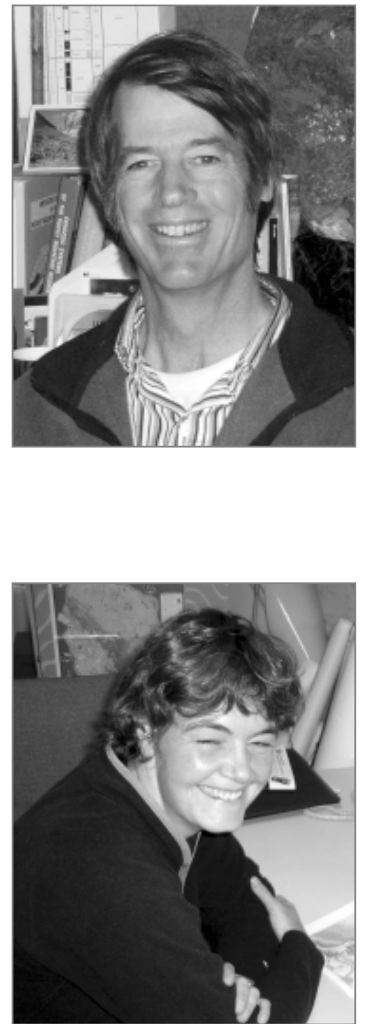